\title{
Analisis Penyerapan Tenaga Kerja Pada Sektor Industri Pengolahan di Provinsi Jawa Timur
}

\author{
(The Analysis of Employment Absorption in the Sector of \\ Manufacturing Industry in East Java Province)
}

\author{
Alfizah Annisaul M*, I Wayan S, Anifatul Hanim \\ Jurusan Ilmu Ekonomi dan Studi Pembangunan, Fakultas Ekonomi dan Bisnis, Universitas Jember (UNEJ) \\ Jln. Kalimantan 37, Jember 68121 \\ E-mail: alfiezah13madridista@gmail.com
}

\begin{abstract}
Abstrak
Penelitian ini bertujuan untuk mengetahui pengaruh Investasi, Ekspor dan Produk Domestik Regional Bruto terhadap penyerapan tenaga kerja pada industri pengolahan di Jawa Timur Tahun 2000-2017, serta melihat hubungan variabel bebas yaitu hubungan investasi terhadap Produk Domestik Regional Bruto dan hubungan ekspor terhadap Produk Domestik Regional Bruto. Data yang digunakan dalam penelitian ini adalah data sekunder berupa data time series tahun 2000-2017 dengan menggunakan metode analisis jalur (path analysis). Berdasarkan analisis yang dilakukan diperoleh hasil investasi berpengaruh positif signifikan terhadap Produk Domestik Regional Bruto, dan Ekspor berpengaruh posistif signifikan terhadap Produk Domestik Regional Bruto, Sedangkan Ekspor berpengaruh positif tetapi tidak signifikan terhadap Produk Domestik Regional Bruto. Sedangkan, Investasi berpengaruh positif tetapi tidak signifikan terhadap penyerapan tenaga kerja sektor industri pengolahan di Provinsi Jawa Timur tahun 2000-2017.
\end{abstract}

Kata Kunci: path analysis, Investasi, Ekspor, Produk Domestik Regional Bruto, Penyerapan Tenaga Kerja.

\begin{abstract}
This research aims to understand the influence of independent investment variable, ekspor, and Gross Regional Domestic Product to dependent variable employment in east java province 2000-2017, and see the relationship of independent variables investment relationship of Gross Regional Domestic Product, variables ekspor relationship of Gross Regional Domestic Product. Data used in this research is secondary data in the form of time series data year 2000-2017 by using path analysis method (path analysis). Based on the analysis, Investment have positive and significant on Gross Regional Domestic Product and export have positive and significant on Gross Regional Domestic Product,the, result of export and Gross Regional Domestic Product have positive and significant effect on labour absorption, while investment has positive but not significant effect on labour absorption of manufacturing sector in East Java Province 2000-2017 year.
\end{abstract}

Keywords: path analysis, investment, Gross Regional Domestic Regional Product, Employment Absorption.

\section{Pendahuluan}

Pembangunan ekonomi yang tinggi dan peningkatan kesempatan kerja merupakan salah satu indikator penting dari pembangunan ekonomi. Pendekatan pertumbuhan ekonomi banyak dilakukan oleh beberapa ahli dan juga di beberapa daerah dalam mengembangkan sektor-sektor ekonomi daerah yang diharapkan dapat membuka peluang kesempatan kerja yang lebih banyak. Landasan teoritis yang memperkuat argument ini adalah model pertumbuhan Harrod-Domar yang didasarkan pada prinsip-prinsip neoklasik dengan asumsi bahwa pertumbuhan ekonomi merupakan indikator adanya kenaikan tingkat kesejahteraan melalui penciptaan lapangan kerja sebagai akibat dari efek multuplier dan efek penetasan kebawah (tricklingdown effect) yang berasal dari tambahan atau perluasan investasi Handoko (2008).

Pembangunan merupakan proses perbaikan disegala bidang kehidupan yang terjadi secara terus-menerus dan berlangsung dalam jangka waktu yang panjang. Pembangunan ekonomi sebagai proses meningkatnya pendapatan riil perkapita penduduk suatu negara dalam jangka panjang yang disertai dengan perbaikan kelembagaan, (Arsyad, 1992). Tujuan dari proses pembangunan suatu Negara adalah untuk meningkatkan kesejahteraan masyarakat dan peningkatan kualitas hidup masyarakat. Proses pembangunan ekonomi diharapkan mampu membawa peningkatan taraf hidup masyarakat menjadi lebih maju dan bermutu khususnya dalam perekonomian. Suryana (2000:23) menjelaskan bahwa proses pembangunan ekonomi akan diikuti oleh beberapa perubahan (growth plus change) yaitu perubahan struktur ekonomi, perubahan yang terjadi dari sektor pertanian menuju sektor industri. Perubahan struktur ekonomi ini dikarenakan perkembangan masa dan teknologi sehingga mengurangi peranan sektor pertanian. Selanjutnya adalah perubahan kelembagaan baik lewat regulasi maupun reformasi kelembagaan itu sendiri. Menurut Simanjuntak (2001) menyebutkan bahwa pembangunan ekonomi yang mengarah pada industrialisasi dapat menjadi penggerak pertumbuhan ekonomi dan juga dalam menyediakan lapangan pekerjaan bagi masyarakat dalam memenuhi pasar tenaga kerja.

Menurut dinas tenaga kerja kesempatan kerja adalah banyaknya orang yang dapat terserap untuk bekerja pada suatu perusahaan atau instansi. Sedangkan secara umum kesempatan kerja diartikan sebagai suatu keadaan yang

* Corresponding author 
mencerminkan jumlah dari total angkatan kerja yang dapat diserap atau ikut secara aktif dalam kegiatan perekonomian. Ketenagakerjaan merupakan masalah utama dan juga menjadi prioritas dalam pembangunan khususnya dalam rangka menurangi pengangguran.

Dimensi dalam masalah ketenagakerjaan dipengaruhi oleh penanaman modal (investasi) dan juga pasar global yang dapat mengakibatkan kemerosotan pertumbuhan industri. Indonesia merupakan negara dengan tingkat pertumbuhan penduduk yang tinggi, peningkatan ini tidak seiring dengan terciptanya lapangan pekerjaan dimana jumlah angkatan kerja yang ada tidak dapat tertampung seluruhnya sehingga mengakibatkan peningkatan pengangguran.Pertambahan penduduk yang berkembang lebih cepat dibandingkan dengan kesempatan kerja menunjukkan bahwa pembangunan ekonomi di negara berkembang tidak mampu meningkatkan kesempatan kerja yang lebih banyak dari peningkatan jumlah penduduk Sukirno (2006:68).

Jawa Timur merupakan salah satu provinsi di Indonesia yang memiliki tingkat pertumbuhan penduduk yang cukup besar sehingga jumlah angkatan kerjanya juga cukup tinggi. Akan tetapi, di Jawa Timur angkatan kerja yang besar tidak diikuti oleh peningkatan kesempatan kerja sehingga tingkat pengangguran di Jawa Timur juga masih cukup tinggi. Oleh karena itu, peneliti ingin meneliti tingkat penyerapan tenaga kerja di Jawa Timur khususnya di sektor industri pengolahan. Berdasarkan data Badan Pusat Statistik (BPS) Jawa Timur Tahun 2017 menunjukkan bahwa Jawa Timur menjadi provinsi dengan jumlah penduduk terbesar di Indonesia dan juga industri pengolahan yang cukup banyak di Indonesia, untuk mengatasi permasalahan baik penyerapan tenaga kerja maupun peningkatan sektor-sektor ekonomi di setiap daerah dapat dilakukan dengan meningkatkan Produk Domestik Regional Bruto, peningkatan Produk Domestik Regional Bruto diharapkan dapat meningkatkan pertumbuhan ekonomi yang selanjutnya akan mendorong tersedianya lapangan kerja baru.

Berdasarkan latar belakang yang telah diuraikan diatas, peneliti tertarik untuk melihat pengaruh investasi, ekspor, dan Produk Domestik Regional Bruto terhadap penyerapan tenaga kerja sektor industri pengolahan di Jawa Timur pada tahun 2000-2017.

\section{Metode}

\section{Jenis dan Sumber Data}

Jenis penelitian ini adalah penelitian explanative research dengan pendekatan kuantitatif yaitu suatu penelitian yang menjelaskan hubungan kausal antara variabel - variabel melalui pengujian hipotesis.

\section{Metode Analisis Data}

Penelitian ini menggunakan Analisis Jalur (Path Analysis) dengan menggunakan aplikasi SPSS versi 22 untuk menganalisis hubungan kausal antara investasi, ekspor, dan pertumbuhan ekonomi baik secara langsung maupun tidak langsung melalui variabel perantara (variabel intervening).

\section{Analisis Jalur (Path Analysis)}

Analisis jalur digunakan untuk menganalisis hubungan sebab akibat antar satu variabel dengan variabel lainnya, Hubungan kausal antar variabel dapat dianalisis menggunakan analisis jalur (path analysis). Signifikansi model tampak berdasarkan koefisien (b) yang signifikan terhadap jalur:

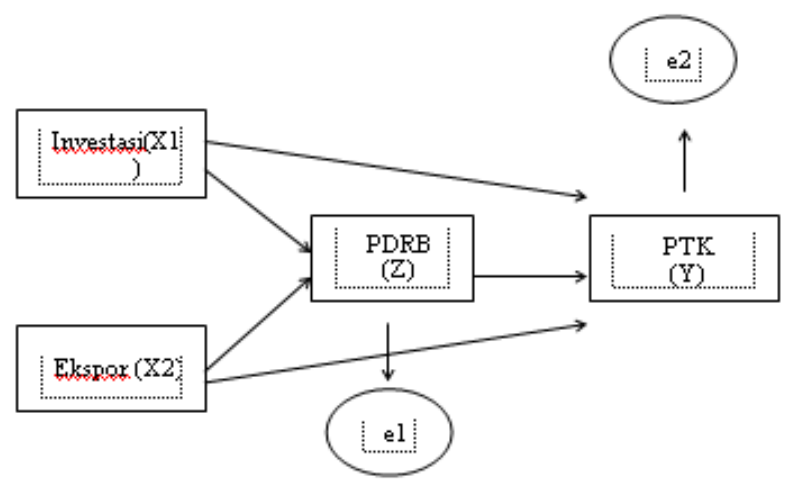

Gambar 1. Model analisis jalur

Model analisis jalur yang digunakan dalam penelitian dapat diuraikan dalam persamaan struktural berikut ini:

$$
\begin{aligned}
& \mathrm{Z}=b 1 \mathrm{X} 1+b 2 \mathrm{X} 2+\mathrm{e} 1 \ldots \ldots \ldots \ldots \ldots \ldots \ldots \ldots \ldots .(\text { Persamaan } 1) \\
& \mathrm{Y}=b 3 \mathrm{X} 1+b 4 \mathrm{X} 2+b 5 \mathrm{Z}+\mathrm{e} 2 \ldots \ldots \ldots \ldots \ldots \ldots \ldots .(\text { Persamaan } 2)
\end{aligned}
$$

Keterangan:

$$
\begin{aligned}
& \mathrm{Y}=\text { Penyerapan Tenaga Kerja } \\
& \mathrm{Z}=\text { Pertumbuhan Ekonomi (PDRB) } \\
& \mathrm{X} 1=\text { Investasi } \\
& \mathrm{X} 2 \quad=\text { Ekspor } \\
& \epsilon 1, \epsilon 2=\text { Variabel Pengganggu }
\end{aligned}
$$

\section{Trimming Theory}

Metode Trimming adalah metode yang digunakan untuk memperbaiki suatu model struktur analisis jalur dengan cara mengeluarkan dari model, variabel bebas yang koefisien jalurnya tidak signifikan Kuncoro et al. (2012).

\section{Hasil dan Pembahasan}

Secara umum, wilayah Provinsi Jawa Timur dibagi menjadi 2 bagian besar yaitu Jawa Timur daratan dan Pulau Madura. Luas wilayah Jawa Timur mencakup 90 persen dari seluruh luas wilayah Provinsi Jawa Timur, sedangkan luas Pulau Jawa hanya sekitar 10 persen. Jawa Timur memiliki jumlah Kabupaten dan Kota terbanyak di Indonesia.

Penduduk merupakan asset pembangunan karena penduduk merupakan penentu dalam perkembangan sebuah pertumbuhan. Di samping itu penduduk juga dapat menjadi beban pembangunan apabila jumlah penduduk tidak diimbangi dengan pemberdayaan sumber daya manusia yang memadai. Jawa timur merupakan salah satu provensi yang memiliki letak strategis di pulau jawa hal ini di karenakan letak jawa timur yang menjadi pintu gerbang perdagangan antara kawasan barat dengan kawasan timur Indonesia. Posisi strategis ini menjadikan kegiatan perekonomian di jawa timur berkembang dengan baik.

Penyerapan tenaga kerja merupakan jumlah dari tenaga kerja yang bekerja dalam suatu unit usaha. Jawa Timur merupakan wilayah dengan jumlah industri pengolahan yang cukup banyak dan juga sektor industri pengolahan di Jawa Timur memberikan kontribusi besar dalam menyerap tenaga kerja. Penyerapan tenaga kerja pada sektor indusri pengolahan dapat dilihat pada tabel berikut: 
Tabel 1. Tenaga Kerja yang Terserap Pada Sektor Industri Pengolahan di Jawa Timur 2000-2017

\begin{tabular}{ccc}
\hline Tahun & Tenaga Kerja & Pertumbuhan(\%) \\
\hline 2000 & 2.141 .870 & 2,06 \\
2001 & 2.234 .995 & 4,35 \\
2002 & 2.306 .514 & 3,20 \\
2003 & 2.341 .112 & 1,50 \\
2004 & 2.404 .922 & 2,73 \\
2005 & 2.464 .565 & 2,48 \\
2006 & 2.536 .628 & 2,92 \\
2007 & 2.575 .731 & 1,55 \\
2008 & 2.591 .185 & 0,60 \\
2009 & 2.643 .871 & 2,03 \\
2010 & 2.785 .082 & 5,34 \\
2011 & 3.025 .473 & 8,63 \\
2012 & 3.069 .575 & 1,46 \\
2013 & 3.115 .680 & 1,50 \\
2014 & 3.133 .049 & 0,56 \\
2015 & 3.151 .221 & 0,58 \\
2016 & 3.163 .511 & 0,39 \\
2017 & 3.016 .837 & 0,41 \\
\hline
\end{tabular}

Sumber : Badan Pusat Statistik (2017)

Berdasarkan Tabel 4.2 dapat diketahui bahwa penyerapan tenaga kerja di industri pengolahan Jawa Timur tahun 20002017 secara umum selalu mengalami peningkatan. Peningkatan penyerapan tenaga kerja ini terjadi karena industri pengolahan merupakan salah satu sektor penggerak perekonomian yang mampu menyerap tenaga kerja di Jawa Timur. Pertumbuhan penyerapan tenaga kerja tertinggi terjadi pada tahun 2011 yaitu sebesar $8,63 \%$ atau 261.098 orang dari 5,34 atau 148.723 orang pada tahun 2010. Adapun determinan penyerapan tenaga kerja pada industri pengolahan di Jawa Timur antara lain Investasi, Ekspor dan Produk Domestik Regional Bruto (PDRB)

Analisis Jalur (Path Analysis)Analisis jalur berkaitan dengan studi ketergantungan suatu variabel independen atau intervening dengan tujuan untuk mengetahui seberapa besar pengaruh variabel independen atau intervening terhadap variabel dependen. Hasil analisis jalur antara variabel independen yaitu investasi dan ekspor dan variabel intervening yaitu PDRB serta variabel dependen yaitu penyerapan tenaga kerja pada industri pengolahan (PTK). Berikut hasil analisis jalur:

Tabel 2. Hasil Analisis Jalur

\begin{tabular}{cccccc}
\hline Jalur & $\begin{array}{c}\text { Unstandardized } \\
\text { Beta }(\boldsymbol{\beta})\end{array}$ & Thitung & Ttabel & Sig. & Keterangan \\
\hline $\mathrm{X} 1 \rightarrow \mathrm{Z}$ & 0,405 & 2,510 & $>2,131$ & 0,023 & Signifikan \\
$\mathrm{X}_{2} \rightarrow \mathrm{Z}$ & 0,511 & 2,714 & $>2,131$ & 0,019 & Signifikan \\
$\mathrm{X} 1 \rightarrow \mathrm{Y}$ & 0,063 & $0,741<2,131$ & 0,471 & Tidak \\
& & & & & Signifikan \\
$\mathrm{X} 2 \rightarrow \mathrm{Y}$ & 0,185 & $2,222>2,131$ & 0,043 & Signifikan \\
$\mathrm{Z} \rightarrow \mathrm{Y}$ & 0,842 & $8,677>2,131$ & 0,000 & Signifikan \\
$\varepsilon 1$ & 0,310 & & & - & - \\
$\varepsilon 2$ & 0,293 & & & - & - \\
\hline
\end{tabular}

Berdasarkan koefisien jalur pada Tabel 2, maka persamaan yang dapat dibentuk adalah ;

$\mathrm{Z}=0,423 \mathrm{X} 1+0,511 \mathrm{X} 2+0,251 \varepsilon 1$

$\mathrm{Y}=0,063 \mathrm{X} 1+0,185 \mathrm{X} 2+0,842 \mathrm{Z}+0,293 \varepsilon 2$

Berdasarkan hasil analisis regresi linear berganda ( dalam hal ini untuk menguji pengaruh secara parsial ) diperoleh hasil yang dapat dinyatakan berikut :

1. Variabel investasi berpengaruh secara signifikan terhadap PDRB dengan nilai koefisien investasi sebesar 0,423 yang berarti bahwa apabila investasi naik sebesar 1 milyar rupiah maka akan meningkatkan PDRB sebesar 0,423 milyar rupiah dengan asumsi variabel lain dianggap tetap dan konstan;

2. Variabel ekspor berpengaruh secara signifikan terhadap PDRB dengan nilai koefisien ekspor sebesar 0,511 yang berarti bahwa apabila ekspor naik sebesar 1 USD rupiah maka akan meningkatkan PDRB sebesar 0,511 milyar rupiah dengan asumsi variabel lain dianggap tetap dan konstan;

3. Variabel investasi tidak berpengaruh secara signifikan terhadap penyerapan tenaga kerja dengan nilai koefisien investasi sebesar 0,063 yang berarti bahwa peningkatan investasi secara langsung tidak dapat meningkatkan penyerapan tenaga kerja;

4. Variabel ekspor berpengaruh secara signifikan terhadap penyerapan tenaga kerja adalah dengan nilai koefisien ekspor sebesar 0,185 yang berarti bahwa apabila ekspor naik sebesar 1 USD maka akan meningkatkan penyerapan tenaga kerja sebesar 0,185 dengan asumsi variabel lain dianggap tetap dan konstan;

5. Variabel PDRB berpengaruh secara signifikan terhadap penyerapan tenaga kerja adalah dengan nilai koefisien PDRB sebesar 0,842 yang berarti bahwa apabila PDRB naik sebesar 1 milyar rupiah maka akan meningkatkan penyerapan tenaga kerja sebesar 0,842 orang dengan asumsi variabel lain dianggap tetap dan konstan;

6. Pengaruh $\varepsilon 1$ variabel lain selain X1 terhadap

$=\sqrt{ } 1-\mathrm{R}$

$=\sqrt{ } 1-0,864$

$=\sqrt{ } 0,136$

$=0,368$ atau $36,8 \%$

7. Pengaruh $\varepsilon 2$ variabel lain selain $\mathrm{X} 1, \mathrm{X} 2$ dan $\mathrm{Z}$ terhadap $\mathrm{Y}$

$=\sqrt{ } 1-\mathrm{R}$

$=\sqrt{ } 1-0,911$

$=\sqrt{ } 0,089$

$=0,298$ atau $29,8 \%$

\section{Trimming Theory}

Berdasarkan perhitungan pada uji analisis jalur diatas, terdapat satu variabel yang tidak mempunyai pengaruh yang signifikan atau melebihi nilai $\alpha$ (alpha) yang telah ditentukan sebelumnya. Jalur yang tidak signifikan tersebut harus diberlakukan trimming theory. Pemberlakuan trimming theory dilakukan dengan menentukan jalur yang baru dan menganalisis kembali pada path diagram yang lama. 
Berdasarkan hal tersebut maka berikut ini disajikan sistematika jalur path diagram yang baru.

Tabel 3. Hasil Analisis Jalur setelah dilakukan trimming theory

\begin{tabular}{cccccc}
\hline Jalur & $\begin{array}{c}\text { Unstandardized } \\
\text { Beta }(\beta)\end{array}$ & Thitung & Ttabel & Sig. & Keterangan \\
\hline $\mathrm{X}_{1} \rightarrow \mathrm{Z}$ & 0,423 & 2,534 & $<2,131$ & 0,023 & Signifikan \\
$\mathrm{X}_{2} \rightarrow \mathrm{Z}$ & 0,505 & $2,671>2,131$ & 0,019 & Signifikan \\
$\mathrm{X}_{2} \rightarrow \mathrm{Y}$ & 0,198 & $2,471>2,131$ & 0,026 & Signifikan \\
$\mathrm{Z} \rightarrow \mathrm{Y}$ & 0,882 & $11,021<2,131$ & 0,000 & Signifikan \\
$\varepsilon 1$ & 0,251 & & & - & - \\
$\varepsilon 2$ & 0,298 & & & - & - \\
\hline
\end{tabular}

Berdasarkan koefisien jalur pada Tabel 4.8, maka persamaan yang dapat dibentuk adalah ;

$\mathrm{Z}=0,423 \mathrm{X} 1+0,505 \mathrm{X} 2+0,251 \varepsilon 1$

$\mathrm{Y}=0,198 \mathrm{X} 2+0,882 \mathrm{Z}+0,298 \varepsilon 2$

Hasil analisis regresi berganda adalah untuk mengetahui pengaruh investasi, ekspor, dan variabel intervening yaitu PDRB, serta variabel dependen yaitu: penyerapan tenaga kerja pada sektor industri pengolahan. Berdasarkan hasil analisis regresi linier berganda (dalam hal ini untuk menguji pengaruh secara parsial) diperoleh hasil yang dapat dinyatakan sebagai berikut:

1. Variabel investasi berpengaruh secara signifikan terhadap PDRB nilai koefisien investasi sebesar 0,423 yang berarti bahwa apabila investasi naik sebesar 1 milyar rupiah maka akan meningkatkan PDRB sebesar 0,423 milyar rupiah dengan asumsi variabel lain dianggap tetap dan konstan;

2. Variabel ekspor berpengaruh secara signifikan terhadap PDRB nilai koefisien investasi sebesar 0,505 yang berarti bahwa apabila ekspor naik sebesar 1 milyar rupiah maka akan meningkatkan PDRB sebesar 0,505 milyar rupiah dengan asumsi variabel lain dianggap tetap dan konstan;

3. Variabel ekspor berpengaruh secara signifikan terhadap penyerapan tenaga kerja adalah dengan nilai koefisien ekspor sebesar 0,198 yang berarti bahwa apabila ekspor naik sebesar 1 milyar maka akan meningkatkan penyerapan tenaga kerja sebesar 0,198 milyar rupiah dengan asumsi variabel lain dianggap tetap dan konstan;

4. Variabel PDRB berpengaruh secara signifikan terhadap penyerapan tenaga kerja adalah dengan nilai koefisien PDRB sebesar 0,882 yang berarti bahwa apabila PDRB naik sebesar 1 milyar rupiah maka akan meningkatkan penyerapan tenaga kerja sebesar 0,882 orang dengan asumsi variabel lain dianggap tetap dan konstan;

5. Pengaruh $\varepsilon 1$ variabel lain selain $X 1$ terhadap

$=\sqrt{ } 1-\mathrm{R}$

$=\sqrt{ } 1-0,864$

$=\sqrt{ } 0,136$

$=0,368$ atau $36,8 \%$

6. Pengaruh $\varepsilon 2$ variabel lain selain $\mathrm{X} 1, \mathrm{X} 2$ dan $\mathrm{Z}$ terhadap $\mathrm{Y}$

$=\sqrt{ } 1-\mathrm{R}$ $=\sqrt{ } 1-0,911$

$=\sqrt{ } 0,089$

$=0,298$ atau $29,8 \%$

\section{Pembahasan}

Berdasarkan variabel dependen dan variabel intervening yang digunakan dalam model penelitian ini diketahui bahwa investasi berpengaruh signifikan dan bernilai positif terhadap Produk Domestik Regional Bruto (PDRB), ekspor berpengaruh secara signifikan terhadap Produk Domestik Regional Bruto (PDRB), investasi tidak berpengaruh signifikan terhadap penyerapan tenaga kerja, ekspor berpengaruh secara signifikan terhadap penyerapan tenaga kerja serta Produk Domestik Regional Bruto (PDRB) berpengaruh secara signifikan terhadap penyerapan tenaga kerja sektor industri pengolahan di Provinsi Jawa Timur pada tahun 2000-2017.

Berdasarkan hasil analisis jalur (Path Analysis) investasi berpengaruh secara signifikan terhadap Produk Domestik Regional Bruto (PDRB) sektor industri pengolahan di Provinsi Jawa Timur pada tahun 2000-2017 artinya setiap kenaikan dalam investasi akan meningkatkan Produk Domestik Regional Bruto (PDRB) di suatu daerah karena investasi merupakan suatu kegiatan penanaman modal untuk kegiatan produksi sehingga nilai investasi yang ditanamkan dapat menambah hasil produksi (output). Total produksi merupakan jumlah produksi atau keseluiruhan jumlah barang yang merupakan hasil akhir proses produksi pada suatu unit usaha yang selanjutkan akan dijual sampai ke tangan konsumen. Dan dengan adanya penambahan investasi maka akan meningkatkan total output yang dihasilkan oleh suatu industri hal ini sama seperti yang dikatakan Mohammed (2006) yang mengatakan bahwa pembentukan modal baru atau invrestasi dapat memperbesar kapasitas produksi yang kemudian akan meningkatkan Produk Domestik Regional Bruto (PDRB).

Berdasarkan hasil analisis jalur yang sudah dilakukan ekspor berpengaruh secara signifikan terhadap Produk Domestik Reional Bruto (PDRB) sektor industri pengolahan di Jawa Timur tahun 2000-2017. Artinya, setiap ada peningkatan pada ekspor akan diikuti juga oleh peningkatan Produk Domestik Regional Bruto (PDRB), karena dengan adanya ekspor yang meningkat setiap 1 USD nya akan menambah devisa negara sehingga pendapan daerah tersebut juga akan meningkat. Dalam teori ekonomi makro, hubungan antara ekspor dengan peningkatan pendapatan atau tingkat pertumbuhan ekonomi merupakan suatu persamaan identitas, karena ekspor merupakan bagian dari tingkat pendapatan nasional. Sedangkan, jika dilihat dari perspektif teori ekonomi pembangunan, masalah hubungan kedua variabel tersebut tidak tertuju pada masalah indentitas melainkan lebih kepada ekspor dapat menggerakkan perekonomian suatu negara dan mampu menggerakkan seluruh perekonomian yang akan berdampak pada peningktan kesejahteraan masyarakat. Semakin tinggi ekspor suatu negara maka dapat dikatakan bahwa negara tersebut merupakan negara yang produktif, mandiri dan maju. Kaum merkantilis juga menyatakan bahwa kemajuan suatu negara bergantung pada pengelolaan hubungan ekonomi dengan negara lain terutama dalam hal perdagangan. 
Hasil selanjutnya adalah investasi tidak berpengaruh signifikan terhadap penyerapan tenaga kerja sektor industri pengolahan di Jawa Timur. Artinya, peningkatan penyerapan tenaga kerja tidak dapat dilakukan dengan peningkatan investasi, kecuali melalui peningkatan PDRB yaitu apabila investasi meningkat dalam suatu sektor industri, maka PDRB meningkat sehingga pertumbuhan ekonominya akan meningkat yang akan berdampak pada peningkatan jumlah industri pengolahan yang selanjutnya akan menambah tenaga kerja untuk meningkatkan kapasitas produksinya. Seperti yang dijelaskan Shafaruddin et al. (2013), yang menyebutkan bahwa peningkatan jumlah investasi akan memperluas output dan penggunaan tenaga kerja. Jadi apabila investasi meningkat industri akan meningkatkan produksinya dan untuk meningkatkan produksi industri perlu tambahan tenaga kerja didalamnya. Hubungan antara investasi (PMA dan PMDN) dengan kesempatan kerja menurut Harrod-Domar yaitu investasi tidak hanya menciptakan permintaan tetapi juga dapat mempebesar kapasitas produksi. Tenaga kerja yang merupakan salah satu faktor produksi, otomatis penggunaannya juga akan ditingkatkan. Jadi penanaman modal (Investasi) mempengaruhi tinggi rendahnya pertumbuhan ekonomi mencerminkan tingkat pembangunan ekonomi suatu daerah sehingga setiap negara berusaha untuk menciptakan iklim yang dapat meningkatkan investasi yang dapat membuka lapangan pekerjaan sehingga dapat meningkatkan kesempatan kerja.

Selanjutnya adalah ekspor berpengaruh secara signifikan terhadap penyerapan tenaga kerja pada sektor industri pengolahan di Jawa Timur. Artinya, jika ekspor sektor industri pengolahan meningkat maka pendapatan pada sektor industri juga akan meningkan, dengan meningkatnya pendapatan maka suatu industri atau perusahaan akan meningkatkan produksinya untuk lebih meningkatkan ekspor dan dalam meningkatkan produksi atau peningkatan ekspor suatu industri akan menambah tenaga kerja sehingga tingkat penyerapan tenaga kerja pada sektor industri juga akan meningkat. Seperti yang dijelaskan oleh Dewi \& Sutrisna (2013) bahwa nilai suatu barang diukur dengan banyaknya tenaga kerja yang digunakan untuk menghasilkan barang. Makin banyak tenaga kerja yang digunakan akan makin tinggi nilai barang tersebut (labor theory of value).

Hasil Selanjutnya adalah PDRB berpengaruh secara signifikan terhadap penyerapan tenaga kerja sektor industri pengolahan di Provinsi Jawa Timur pada tahun 2000 sampai 2017. Artinya, jika Produk Domestik Regional Bruto (PDRB) maka industri akan meningkatkan kapasitas produksinya yang selanjutnya akan merangsang peningkatan penyerapan tenaga kerja pada sektor tersebut. Produk Domestik Regional Bruto (PDRB) dapat mempengaruhi jumlah angkatan kerja yang bekerja dengan asumsi bahwa, apabila nilai Produk Domestik Regional Bruto (PDRB) meningkat, maka jumlah nilai tambah output atau penjualan dalam seluruh unit ekonomi disuatu wilayah juga akan meningkat, semakin besar output atau penjualan yang dilakukan oleh suatu industri maka akan mendorong unit industri untuk menambah permintaan tenaga kerja agar produksinya dapat ditingkatkan untuk mengejar peningkatan penjualan tersebut.

\section{Simpulan}

Pemaparan hasil analisis dengan menggunakan metode analisis jalur (Path Analysis) yang telah dipaparkan sebelumnya dapat diambil kesimpulan sebagai berikut:

1. Investasi berpengaruh secara signifikan terhadap Produk Domestik Regional Bruto di Provinsi Jawa Timur Tahun 2000-2017 dengan nilai koefisisen 0,405 yang artinya nilai Produk Domestik Regional Bruto dapat ditingkatkan melalui peningkatan investasi.

2. Investasi tidak berpengaruh signifikan terhadap penyerapan tenaga kerja sektor industri pengolahan di Provinsi Jawa Timur Tahun 2000-2017 dengan nilai koefisien 0,063 yang artinya peningkatan penyerapan tenaga kerja tidak dapat dilakukan melalui peningkatan investasi.

4. Ekspor berpengaruh secara signifikan terhadap Produk Domestik Regional Bruto di Provinsi Jawa Timur Tahun 2000-2017 dengan nilai koefisien 0,511, artinya semakin besar ekspor maka Produk Domestik Regional Bruto juga akan bertambah.

5. Ekspor berpengaruh secara signifikan terhadap penyerapan tenaga kerja industri pengolahan di Provinsi Jawa Timur Tahun 2000-2017 dengan nilai koefisien 0,198 artinya peningkatan ekspor dapat meningkatkan penyerapan tenaga kerja sektor industri pengolahan.

6. Produk Domestik Regional Bruto berpengaruh secara signifikan terhadap penyerapan tenaga kerja industri pengolahan di Provinsi Jawa Timur Tahun 2000-2017 dengan nilai koefisien 0,882 yang artinya peningkatan Produk Domestik Regional Bruto dapat meningkatkan penyerapan tenaga kerja sektor industri pengolahan.

\section{Saran}

Berdasarkan kesimpulan dari hasil penelitian, maka penulis memberikan beberapa saran yang berkaitan dengan penelitian yang telah dilakukan untuk dijadikan bahan masukan dan pertimbangan, adapun saran-saran yang dapat diberikan melalui hasil penelitian adalah sebagai berikut:

\section{Bagi Pemerintah Daerah}

a. Pemerintah sebaiknya mendorong dan mempermudah investor untuk menanamkan modal serta mengembangkan unit usaha pada industri pengolahan sehingga dapat meningkatkan penyerapan tenaga kerja.

b. Hal ini dapat dilakukan dengan memberikan kemudahan perizinan kepada investor yang akan berinvestasi serta mempermudah pemberian pinjaman modal kepada pengusaha industri pengolahan.

c. Sektor industri pengolahan di Jawa Timur merupakan sektor ekonomi yang unggul dibandingkan sektor lain sehingga memberikan manfaat yang strategis dalam penyerapan tenaga kerja dan mampu mengurangi pengangguran yang ada.

d. Sebagai pengambil keputusan, pemerintah dihimbau untuk selalu memperhatikan perkembangan industri pengolahan 
khususnya ekspor setiap periodenya agar sektor industri manufaktur dapat terus meningkatkan ekspor sehingga dapat menyerap tenaga kerja lebih banyak lagi.

\section{Bagi Peneliti Selanjutnya}

Diharapkan bagi peneliti yang ingin meneliti dengan tema yang sama hendaknya menambah tahun penelitian dan menggunakan variabel-variabel lain shingga hasil penelitian yang selanjutnya dapat lebih berkembang dan bermanfaat.

\section{Referensi}

Arsyad, L. (1992). Pembangunan Ekonomi (2nd ed.). STIEYKPN.

Dewi, N. M. S., \& Sutrisna, I. K. (2013). Pengaruh Investasi dan Ekspor Terhadap Penyerapan Tenaga Kerja Melalui Pertumbuhan Ekonomi. E- Jurnal EP Unud, 4, 4(6), 621-636.
Handoko, T. H. (2008). anajemen Personalia dan Sumber Daya Manusia. Yogyakarta: BPFE Pres.

Kuncoro, A., Engkos, \& Ridwan. (2012). Análisis jalur (Path Análisis) (2nd ed.). Alfabeta, Bandung.

Mohammed, S. (2006). Pasar Modal dan Manajemen Portofolio. Jakarta: Erlangga.

Shafaruddin, R., Arkanudin, \& Suryadi, A. (2013). Persepsi Mahasiswa Terhadap UPT. Perpustakaan Universitas Tanjungpura. Jurnal Tesis PMIS-UNTAN-PSS-2013, 1-12.

Simanjuntak, P. J. (2001). Pengantar Ekonomi Sumber Daya Manusia. LPFEUI.

Sukirno. (2006). Mikro Ekonomi Teori Pengantar (3rd ed.). Rajagrafindo Persada.

Suryana. (2000). Ekonomi Pembangunan: Problematika dan Pendekatan (4th ed.). Salemba Empat. 